\title{
Natural Regeneration and Tree Species Composition of Mixed Deciduous Forest after Logging and Shifting Cultivation in Lao PDR
}

\author{
Chanhsamone Phongoudome ${ }^{1 *}$, Don Koo Lee ${ }^{2}$, Silavanh Sawathvong ${ }^{3}$, \\ Marilyn S. Combalicer ${ }^{4}$
}

${ }^{1} \mathrm{Ph} . \mathrm{D}$ Candidate, Silviculture and Restoration Ecology Laboratory, Department of Forest Sciences, College of Agriculture and Life Sciences, Seoul National University, Seoul, 151-921, Korea

${ }^{2}$ Professor, Silviculture and Restoration Ecology Laboratory, Department of Forest Sciences, College of Agriculture and Life Sciences, Seoul National University, Seoul, 151-921, Korea

${ }^{3}$ Director General, Department of Forestry,

Ministry of Agriculture and Forestry, Vientiane, Lao PDR

${ }^{4}$ Professor, College of Forestry, Nueva Vizcaya State University, Bayombong, Nueva Vizcaya 3700, Philippines

\begin{abstract}
Shifting cultivation and logging are serious problems in tropical countries like Laos which contribute to a large extent in the increase of deforestation. In this study, stand structure, species composition and diversity, soil chemical properties and microclimate were determined to compare the natural regeneration patterns of primary and secondary forests (logged-over and fallow) of mixed deciduous forests after logging and shifting cultivation in Laos. All woody species with stem diameter of $\geq 5 \mathrm{~cm}$ were identified and counted. Diameter at breast height $(\mathrm{DBH})(1.3 \mathrm{~m})$ was measured in all plots. The distance time to recovery was also compared among the sites. The family and species composition were increase from 25 species and 15 families, 31 species and 21 families, 44 species and 24 families, 45 species and 25 families after slash and burn for 1-year, 5- year, 10-year, 15-years fallow periods. While, species composition was increased 82 species and 30 families in logged-over secondary forest if compared to 77 species and 35 families found in primary forest. Three pioneer species were higher importance value such as Schima wallichii in primary forest, Cratoxylum cochinchinensis in 15, 10 and 5-year-old fallow and Aporosa microcalyx in 1-year-old fallow. The basics data obtained in this study will be very useful in managing secondary forests in the future.
\end{abstract}

Keywords: fallow, logged-over, microclimate, mixed deciduous forest, natural regeneration, recovery, shifting cultivation, soil chemical properties, species composition, stand structure

\section{Introduction}

The tropics and sub-tropics were about $56 \%$ of the total world's forests, which higher level rate of deforestation were recorded (FAO, 2001). In these areas, shifting cultivation, logging and fuel-wood and wood charcoal consumption are very common problems (FAO, 2006; Mertz et al., 2009; Lawrence et al., 2010). The main drivers of deforestation and forest degradation in Laos was mainly shifting cultivation, followed by logging, infrastructure development, land conversion to agriculture and industrial activities (MAF 2005b; GoL 2006; Phongoudome and Sirivong 2007). In Laos alone, it has been estimated that more than 6.5 million ha of forests (28.2\% of the total land area) are affected by shifting cultivation involving about $17 \%$ of the human populations (Messerli et al., 2009; Sovu et al., 2009; Schmidt-Vogt et al., 2009). In Laos rehabilitation and restoration of forests in Laos are mainly based on natural regeneration and plantation. The government aims to increase the national forest cover of up to $70 \%$ by the year 2020 through establishment of more than 6 million ha by natural regeneration and 0.5 million ha by plantations especially in degraded forests including fallow forests and logged-over forests as stipulated in the Forestry Strategy 2020 (MAF, 2005a). Tropical mixed deciduous forests are the most extensive and important tropical vegetation in Laos, which was about 8.6 million ha in 1982 and 6.3 million ha (62\% of total current forest) in 2002 (MAF, 2005b).

Restoration by natural regeneration or man-made approaches using native species is becoming common in forest ecosystem management and may contribute to the improvement of forest environmental conditions (Jordan et al., 1987; Brown and Lugo, 1990; Urbanska et al., 1997; Sayer et al., 2004). Currently, tropical forests and trees are becoming subjects of concern because of its species diversity (Condit et al., 1996; de Jong and Chokkalingam, 2001). Basic information on species composition would be useful in evaluating the impact of previous forest activity. It can also indicate the capability of forest recovering from past disturbances, so the information can be used for planning and better management of forests on a sustainable forest management basis. If forest is to be regarded as a renewable resource good forestry practices must be designed to prevent wastage and damage to the standing stock and environmental protection must be carried out during harvesting (Faridah et al., 1999). Tree species diversity contributes to the forest ecosystem stability and sustainable developments (Rennolls and Laumonier, 2000). Floristic inventory is necessary for much fundamental research in tropical community ecology, such as modelling patterns of species diversity or understanding species distribution. It is because forest communities are dynamic and individual and species composition levels are changing continuously (Felfili, 1995; Phillips et al., 2003). Only few in depth studies have characterized tree species composition and stand structure of forests in Laos. Thus, this study was conceptualizes with the main objective of comparing the natural regeneration patterns of logged-over and fallow forests of secondary mixed deciduous in Laos after logging and shifting cultivation using primary forest as a control.

\section{Materials and Methods Site description}

The study was conducted in Bolikhan District, Bolikhamxay Province, in the central part of Laos. It is about $185 \mathrm{~km}$ from the Vientiane Capital City to the south and situated between the $18^{\circ}$ $30^{\prime}$ to $18^{\circ} 40^{\prime} \mathrm{N}$ latitude and $103^{\circ} 36^{\prime}$ to $103^{\circ} 42^{\prime}$ E longitude. The elevation ranges from $165-175 \mathrm{~m}$ above sea level (a.s.l.), with a slope of 2-5 degrees. The mean temperature for a decade (20002009) ranged from $21.4 \mathrm{C}^{\circ}$ to $31.2 \mathrm{C}^{\circ}$ and the mean annual rainfall ranged from 2,000-2,700 $\mathrm{mm}$. The tropical mixed deciduous forests in the study site cover a primary forest with 719 ha, 
secondary logged-over forest with 5,323 ha, secondary fallow forest with 8,496 ha and non-forest with 414 ha (Figure 1). The first selective cutting method was carried out in the natural forest in 1983-84 and second in 1994-95 by the State Forest Enterprise Company. This practice followed by human activities such as several years of shifting cultivation, fuel-wood collection and charcoal making after timber harvesting seriously affected the forests in this area.

\section{Stand measurement}

The number and size of sample plots established in each forest type were different due to the area coverage of the coverage of the study area. A total of 180 plots ( 30 plots in 6 sites) with $20 \mathrm{~m} \mathrm{x} 20$ $\mathrm{m}$ size were systematically established in the study area (7.2 ha). Species, diameter at breast height of all trees (DBH $\geq 5 \mathrm{~cm}$ ), height, and canopy cover of each tree were measured in each plot. Equations used for stand structure and species composition analysis are shown in Table 1 . For measuring the saplings height $(>1.3 \mathrm{~m})$ and DBH $(<5 \mathrm{~cm})$ a sub-plot of $5 \mathrm{~m} \times 5 \mathrm{~m}$ was established. While, for measuring seedlings' height $(<1.3 \mathrm{~m})$, a sub-plot of $2 \mathrm{~m}$ x $2 \mathrm{~m}$, was established.

\section{Litter layer}

To determine the amount of litters in the litter layer, a sub-plot (1 $\mathrm{m} \times 1 \mathrm{~m}$ ) was established in each plot during inventory period. Litters were collected and weighed. Samples were than brought to the laboratory of Forest Research Centre (FRC) and were oven dried for 24 to 48 hours at $70^{\circ} \mathrm{C}$ until constant weight. The dried weight was recorded.

\section{Soil analysis}

At the center of each plot, soil sample was collected at $20 \mathrm{~cm}$ depth. The samples obtained were brought to the Soil Research Centre (SRC), National Agriculture and Forestry Research Institute (NAFRI), Laos for analyzing the soil chemical properties such as $\mathrm{pH}\left(\mathrm{H}_{2} \mathrm{O}\right), \mathrm{pH}(\mathrm{Kcl})$, total $\mathrm{N} \%, \mathrm{P}$ available, $\mathrm{K}$ available, soil organic matter (SOM), soil organic carbon $\%, \mathrm{C}$ and $\mathrm{N}$ ratio, cation exchange $\mathrm{C}^{++}, \mathrm{Mg}^{++}, \mathrm{Na}^{++}$, and $\mathrm{K}^{++}$.

\section{Micro-climate data collection}

Three portable HOBO data loggers were launched in each stand at an above ground height of $3 \mathrm{~m}$ to measure air temperature and relative humidity during the research period. All data were automatically collected with one-hour interval (BoxCar Pro 4.0 Onset Computer Corporation, USA).

\section{Data analysis}

The mean value and standard errors of vegetation parameters and soil chemical properties were analyzed using MS Excel 2007 and SAS 9.1.3 for Windows 2007 (SAS Institute Inc., USA) Duncan's Multiple Range Test (DMRT) was used to examine the different soil chemical properties in the forests. The significance for all analyses was determined at $\alpha=0.05$.

\section{Results and Discussion}

\section{Vegetation characteristics of primary, secondary logged-over and secondary fallow forest in Laos}

A total of 123 tree species and 40 families were found in the study site (DBH $\geq 5 \mathrm{~cm}$ ). The number of species and families increased with increasing fallow age. For instance, 25 species and 15 families, 31 species and 21 families, 44 species and 24 families, 45 species and 25 families were recorded for after slash and burn activities in the area for 1-year, 5-years, 10-years and 15-years fallow period, respectively. This is similar with the studies of Vieira et al., (2006), Faria et al., (2009) and Mostacedo et al., (2009) where 1 to 10 years after slash and burn, most natural regeneration was based on soil seed bank, root suckers and root sprout or stump sprout and species composition increased with increasing fallow periods (Fukushima et al. 2007; Fukushima et al. 2008; Sovu et al., 2009; Tran et al., 2010). There were 82 species and 35 families in the primary forest, while 77 species and 30 families in the loggedover secondary forest (Table 2). This study found out that after logging canopy was became open and the number of species increased by 5 species. However, selective logging has also positive and negative effects on tree species diversity (Brown 1998; Van-Gemenden et al., 2003).

The stem density ( $\mathrm{DBH} \geq 5 \mathrm{~cm}$ ) was highest $(1,153 / \mathrm{ha}$ ) in 10 -yearold fallow forest and lowest (12/ha) in 1-year-old fallow forest. The competition among species from year one was not high as the starting point of recover is on 10-year-old fallow period. It is can maximize growth from (soil seed bank, root and stump sprout) and dispersal of seeds from remaining forests is possible. Most of the DBH classes ranged from $5-10 \mathrm{~cm}$ and $11-15 \mathrm{~cm}$, while height classes ranged from 1-5 m and 6-10 $\mathrm{m}$. The highest stem density in saplings and seedlings was $10,563 / \mathrm{ha}$ and $8,393 / \mathrm{ha}$, respectively in 15-year-old fallow forest. In tropical forest some species are already producing seed during 15 -year-old. At the same time, seedlings from soil seed bank as well as, root and stump sprout continue to growth into saplings. The growth patterns for height and DBH exhibits reverse J-shape or L-shape as shown in Figure 2.

Species composition diversity has been one of the basic concepts of ecology used to characterized communities and ecosystem, and environment heterogeneity has strong effects on species diversity (Whitmore, 1998). This study found out that species composition and diversity index were affected by logging and shifting cultivation. The vegetation characteristics in the primary and secondary forests (logged-over and fallow) are shown in Table 2. The Shannon diversity index increased from 2.13 to 2.91 in 1-year-old to 15-year-old fallow period or if compared to primary forest 3.40 and in logged-over forest 3.09. The results of this study will serve as a basic for conservation and restoration times frame which is needed in forest management, e.g. selective logging by strip clear-cuts methods (Hartshorn, 1989; Fredericksen and Mostacedo, 2000; Vieira and Scariot, 2006; Villela et al., 2006).

The changes in importance value (IV) of different tree species in the primary and secondary forests (logged-over and fallow) are indicated in Table 3. Schima wallichii had higher IV $(17.22 \%)$ in the primary forest. While, Cratoxylum cochinchinensis had higher IV in the secondary logged-over forest, 15-year, 10-year, and 5 -year-old secondary forests $16.20 \%, 15.99 \%$ and $16.20 \%$, $15.99 \%, 17.31 \%$ and $9.67 \%$, respectively). In 1-year-old secondary fallow forest, it was found out that Aporosa microcalyx had the highest IV $22.47 \%$. The pioneer tree species were play important role for natural regeneration in tropical forest studies, when the forest succession most of them are distribution in second and third storey (Lamb et al., 2005; Kariuki et al., 2006; Sovue et al., 2009; Tran et al., 2010).

The success of natural regeneration depends on seed banks in soil, seed rain, seedling banks and seed dispersal or predation, stump sprouts, root sprouts, layering, and native tree species remain. Other factors re condition of forest, level of disturbances, management system, and environmental condition (Kennard et al., 2002; Parrotta et al., 2002; Okuda et al., 2003; Lamb et al., 2005)

Most of natural regenerations in southeast Asia and other tropical developing countries after logging and shifting cultivation focuses 
on economic consideration for the next felling rotation or estimated times of recovery, such as 30-120 years of stabilization period (Kariuki et al., 2006; Read and Lawrence, 2003; Fukushima et al., 2007) and 150-500 years (Riswa et al., 1985; Katawinara, 1994) for returning to original condition, than the important role of environment and diversity. However, silvicultural techniques by assistant natural regeneration such as enrichment planting, direct seeding and mixed plantation of native or exotic tree species can also increased biodiversity in the future (Chazdon, 2003; van Gemerden et al., 2003; Tran et al., 2005; Bischoff et al., 2005). Therefore, species composition and structure and their natural regeneration or assistant natural regeneration in tropical rainforest or tropical deciduous forest (Jordan et al., 1987; Kennard et al., 2002; Hardwick et al., 2004) must be fully understood in conducting research.

\section{Changes in soil chemical properties after logging and shifting cultivation}

This study shows that 5-year-old secondary fallow forest had higher air temperature (AT) ranging from 8 to $48^{\circ} \mathrm{C}$ in dry season (November 2007 to July 2008) and relative humidity (RH) ranging from 35 to $84 \%$ in October 2007. The AT and RH slightly decline from May 2007 to July 2008 ( 8 to $38^{\circ} \mathrm{C}$ and 35 to $95 \%$, respectively) in between 10 and 15-year-old fallows, but RH of logged-over secondary forest and primary forest became $\left(8\right.$ to $35^{\circ} \mathrm{C}$ and 25 to $85 \%$ ).Microclimate is a host of climatic variables unique to a specific location at a specific time and forest types (Meyer et al., 2001). In humid tropical forest, (RH) is higher in forested than cleared area during rainy months, but affected areas are less pronounced during dry months. According to Ghuman and Lal (1986), (AT) during rainy season is lower by $1-5^{\circ} \mathrm{C}$ under forested than cleared land area. In leaves of an oak-hornbeam forest, approximately $50 \%$ of incident photo-synthetically active radiation (PAR) was absorbed by the upper $4 \mathrm{~m}$ layer of leaves and only less than $5 \%$ penetrated to the forest floor. While, vertical gradients of AT and RH were generally low, but large differences in diurnal ranges of AT and RH were observed between vertical levels (Elias et al., 1989). In clear-cut beech forest there was strong correlation between microclimatic parameters and distance from the forest edge (Godefroid et al., 2006). Microclimate, especially the thermal regime of the microenvironment, is very important in forest management (Kimmins, 1997; Weng et al., 2007; Zhu et al., 2007; Stoffel et al., 2010).

\section{Conclusions}

Natural regeneration of secondary forest after logging, shifting cultivation or other disturbances is becoming an important method for restoring degraded forest ecosystem in tropical countries. Therefore, human's assistance is needed to recover forest structure, species composition, and species interaction on secondary forests. This is important in tropical secondary forest and in conserving biodiversity. However, in restoring degraded forestlands, cheapest and easy approach for rehabilitating degraded forest, mixed plantation and agro forestry areas should be considered.

\section{Acknowledgement}

This study was supported by the ASEAN-Korea Environment Cooperation Project (AKECOP) funded from Korea Ministry of Foreign Affairs and Trade, and Ministry of Environment. The authors sincerely thank the peoples and staff foresters in Bolikhan District, Bolikhamxay province for their closed collaboration during 6 years of research.

\section{Reference}

1. Bichoff W, Newbery DM, Lingenfelder M, Schnaeckel R, Petol GH, Madani L, Risdan CE (2005). Secondary succession and dipterocarps recruitment in Bornean rain forest after logging. Forest Ecology and Management 218: 172-192.

2. Brown S (1998). Degeneration versus regeneration logging in tropical rain forests. Pp.43-73. In: Goldsmith, F. B. (Ed.). Tropical Rain Forest A Wider Perspective. Chapman \& Hall. London.

3. Brown S, Lugo AE (1990). Tropical secondary forest. Journal of Tropical Ecology 6: 1-32.

4. Chazdon RL (2003). Tropical forest recovery: legacies of human's impact and natural disturbances. Plant Ecology 6: 51-71.

5. Condit R, Hubbell SP, Lafrankie JV, Sukumar R, Manokaran N, Foster RB, Ashton PS (1996). Species area and species individual relationships for tropical forests: a comparison of three 50-ha plots. Journal of Ecology 84: 549-562.

6. Curtis JT, McIntosh RP (1950). The interaction of certain analytic and synthetic phytosociological characters. Ecology 31:434-455.

7. De Jong W, Chokkalingam UJS (2001). Tropical secondary forests: introduction and synthesis. Journal of Tropical Forest Science 13: 563-567.

8. Eaton JM, Lawrence D (2009). Loss of carbon sequestration potential after several decades of shifting cultivation in southern Yucatan. Forest Ecology and Management 258: 949-958.

9. Elias P, Kratochvirova I, Janous D, Marek M, Masarovicova E (1989). Stand microclimate and physiological activity of tree leaves in an oak-hornbeam forest. Trees 4: 227-233.

10. FAO (2006). Forest resources assessment 2005. Rome Italy.

11. FAO (2001). Forest resources assessment 2000. Rome Italy.

12. Faria D, Mariano-Neto E, Martini AMZ, Ortiz JV, Montingelli R, Rosso S, Paciencia MLB, Baumgarten J (2009). Forest structure in a mosaic of rainforest sites: the effect of fragmentation and recovery after clear cut. Forest Ecology and Management 257: 2226-2234.

13. Faridah HI, Norhisyam TM, Sabri M, Azani AM, Mokhtaruddin AM, Maswa M, Yusoff MK, Majid NM, Kobayashi S (1999). Tree Species composition and above ground biomass of a 15 year old logged over Forest at Pasoh, Negeri Sembilan, Peninsular Malaysia. Pp. 81-86. In: Kobayashi S, Turnbull JW, Toma T, Mori T, Majid NM (Eds). Rehabilitation of degraded tropical forest ecosystems. Workshop Proceedings, 2-4 November 1999, Bogor, Indonesia.

14. Felfili JM (1995). Growth, recruitment and mortality in the Gama gallery forest in central Brazil over six-year period. Journal of Tropical Ecology 11: 67-83.

15. Fredericksen TS, Mostacedo B (2000). Regeneration of timber species following selection logging of Bolivian tropical dry forest. Forest Ecology and Management 131: 47-55.

16. Fukushima M, Mamoru K, Thein HM, Minn Y (2007). Recovery process of fallow vegetation in the traditional Karen swidden cultivation system in Bago mountain range in Myanmar. Southeast Asia Study Volume 45. Kyoto University.

17. Fukushima M, Kanzaki M, Hara M, Ohkubo T, Preechapanya P, Choocharoen C (2008). Secondary forest succession after the cessation of swidden cultivation in the montane forest area in Northern Thailand. Forest Ecology and Management 255: 1994-2006.

18. Ghuman BS, Lal R (1986). Effects of partial clearing on microclimate in a humid tropical forest. Agriculture and Forest Meteorology 40: 17-29. 
19. Godefroid S, Rucquoij S, Koedam N (2006). Spatial viability of summer microclimates and plant species response along transects within clear cuts in a beech forests. Plant Ecology 185: 107-121.

20. Government of Lao (GoL) (2006). Third National Report to UNCCD. Vientiane. Hardwick K, Healey JR, Elliott S, Blakesley D (2004). Research need for restoring seasonal tropical forest in Thailand: accelerated natural regeneration. New Forest 27: 285-320.

21. Hartshorn GS (1989). Application of gap theory to tropical forest management: natural regeneration of strip clear-cuts in Peruvian Amazon. Ecology 70: 567-569.

22. Hashimotio T, Kojima K, Tange T, Sazaki S (2000). Changes in carbon storage in fallow in tropical lowlands of Borneo. Forest Ecology and Management 126: 331-337.

23. Jordan WR, Gilpin ME, Aber JD (1987). Restoration ecology: ecological restoration as a technique for basic research. pp. 3-21. In: Jordan WR, Gilpin ME, Aber JD (Eds). Restoration ecology, Cambridge University Press.

24. Kariuki M, Kooyman RM, Smith RGB, Wardell-Johnson G, Vanclay JK (2006). Regeneration changes in tree species abundance, diversity and structure in logged and unlogged subtropical rainforest over a 36-year period. Forest Ecology and Management 236: 162-176.

25. Kartawinara K (1994). The use of secondary forest species in rehabilitation of degraded forest lands. Journal of Tropical Forest Science 7: 76-86.

26. Kennard DK, Gould K, Putz FE, Fredericksen TS, Morales F (2002). Effect of disturbance intensity on regeneration mechanism in tropical dry forest. Forest Ecology and Management 162: 197-208.

27. Kimmins JP (1997). Forest Ecology. A Foundation for sustainable forest management. Prentic Hall Inc., USA. 596 p.

28. Lamb D, Erskine PD, Parrotta JA (2005). Restoration of degraded tropical forest landscapes. Science 310: 1628-1632.

29. Lawrence D, Foster DR (2002). Change in forest biomass, litter dynamics and soils following shifting cultivation in southern Mexico: an overview. Interciencia 27: 27: 400-408.

30. Lawrence D, D'Odorico P, DeLonger M, Diekmann L, Das R, Eaton JM (2007). Ecological feedbacks following deforestation create the potential for a catastrophic ecosystem shift in tropical dry forest. Proceedings of the National Academy of Science 104: 20696-20701

31. Lawrence D, Radel C, Tully K, Schmook B, Schneider L (2010). Untangling a decline on tropical forest resilience: constraints on the sustainability of shifting cultivation across the globe. Biotropica 42 : 21-30.

32. Magurran AE (1988). Ecological diversity and its measurement. Princeton University Press, Princeton NJ.

33. Mertz O, Leisz S, Heiniman A, Rerkasem K, Thiha Dressler W, Cu PV, Chi VK, Schmidt-Vogt D, Colfer CCJP, Eppecht M, Padoch C, Potter L (2009). Who counts? Demography of swidden cultivations in Southeast Asia. Human Ecology 37: 281-289.

34. Messerli P, Heiniman A, Epprecht M (2009). Finding homogeneity in heterogeneity-a new approach to qualifying landscape mosaics development for the Lao PDR. Human Ecology 37: 291-304.

35. Meyer CL, Sisk TD, Covington WW (2001). Microclimate changes induced by ecological restoration of Ponderosa Pine forests in northern Arizona. Restoration Ecology 9: 443-452.

36. Ministry of Agriculture and Forestry (MAF) (2005a). Forestry Strategy to the year 2020. Vientiane.

37. Ministry of Agriculture and Forestry (MAF) (2005b). Forest covers assessment 2002. Vientiane.
38. Mostacedo B, Putz FE, Fredericksen TS, Villca A, Palacios T (2009). Contributions of root and stump sprouts to natural regeneration of logged tropical dry forest in Bolivia. Forest Ecology and Management 258: 978-985.

39. Neergaard A, Magid J, Merzt O (2008). Soil erosion form shifting cultivation and other smallholder land use in Sarawak, Malaysia. Agriculture, Ecosystem and Environment 125: 182-190.

40. Okuda T, Suzuki M, Adachi N, Uuah ES, Hussein NA, Monokaran N (2003). Effect of selective logging on canopy and stand structure and tree species composition in a lowland dipterocarp forest in peninsular Malaysia. Forest Ecology and Management 175: 297-320.

41. Parrotta JA, Francis JK, Knowles OH (2002). Harvesting intensities effects forest structure and composition in an upland Amazonian forest. Forest Ecology and Management 169: 243-255.

42. Phillips OL, Martinez RV, Vargas PN, Monteagudo AL, Zanc MC, Sanchez WG, Cruz AP, Timana M, Ylihalla M, Rose S (2003). Efficient plot based floristic assessment of tropical forests. Journal of Tropical Ecology 19: 629-645.

43. Phongoudome C, Sirivong K (2007). Forest Rehabilitation and Restoration in Laos. Pp. 57-84. In: Lee DK (Ed), Keep Asia Green Vol. I 'Southeast Asia". IUFRO World Series 20-I. Vienna Austria.

44. Pielou EC (1975). Ecological diversity. Wiley, New York. 165pp.

45. Prasit W (2002). Ecological studies of reduced forest-fallow shifting cultivation of Karen people in Mae Chaem watershed, Northern Thailand. Symposium on 17th WCSS, 14-17 August, Chiang Mai, Thailand.

46. Read L, Lawrence D (2003). Recovery of biomass following shifting cultivation in dry tropical forests of the Yucatan. Ecological Application 13: 85-97.

47. Rennolls K, Laumonier Y (2000). Species diversity and structure analysis of two site of tropical rainforest of Sumatra. Journal of Tropical Ecology 16: 253-270.

48. Riswa S, Kentworthy JB, Kartawinara K (1985). The estimate of temporal processes in tropical rain forest: a study of primary dipterocarps forest in Indonesia. Journal of Tropical Ecology 1: 171-182.

49. Sayer J, Chokkalingam U, Poulsen J (2004). The restoration of forest biodiversity and ecological values. Forest Ecology and Management 201: 3-11.

50. Schmidt-Vogt D, Leisz SJ, Mert O, Heinimann A, Thiba T, Messerli P, Epprecht M, Cu PC, Chi VK, Hardiono M, Dao TM (2009). An assessment of trends in the extent of swidden in Southeast Asia. Human Ecology 37: 269-280.

51. Shannon CE, Weaver WJ (1949). The mathematical theory of communication. University of Illinois Press, Urbana. 117pp.

52. Sist P, Picard N, Gourlet-Fleury G (2004). Sustainable cutting cycle and yield in the lowland dipterocarp in Borneo. Annual Forest Science 60: 803-814

53. Sovu S, Tigabu M, Savadogo P, Oden PD, Xayvongsa L (2009). Recovery of secondary forests on swidden cultivation fallows in Laos. Forest Ecology and Management 258: 2666-2675.

54. Stoffel J, Gower ST, Forrester JA, Mladenoff DJ (2010). Effects of winter selective tree harvest on soil microclimate and surface $\mathrm{CO} 2$ flux of a northern hardwood forest. Forest Ecology and Management 259: 257-265.

55. Tran DV, Osawa A, Nguen TT (2010). Recovery process of mountain forest after shifting cultivation in northwestern Vietnam. Forest Ecology and Management 259: 1650-1659. 
56. Tran VD, Lee DK, Hoang VT (2005). Rehabilitation of the native forest tree species at the forest plantation and denuded hills of Namlau commune in Sonla Province, Vietnam. Forest Science and Technology 1: 51-58.

57. Urbanska KM, Webb NR, Edwards PJ (1997). Restoration ecology and sustainable development. Cambridge University Press.

58. Van-Gemenden B, Shu GN, Olff H (2003). Recovery of conservation value in central African rainforest after logging and shifting cultivation. Biodiversity and Conservation 12: 1553-1570.

59. Vieira DLM, Scariot A (2006). Principles of natural regeneration of tropical dry forests restoration. Restoration Ecology 14: 11-20.

60. Vieira DLM, Scariot A, Sampaio AB, Holl KD (2006). Tropical dry forest regeneration from root suckers in central Brazil. Journal of Tropical Ecology 22: 353-357.

61. Villela DM, Nascimento MT, Aragao LEOC, Gama DM (2006). Effect of selective logging on forest structure and nutrient cycling in seasonal dry Brazilian forests. Journal of Biogeography 33: 516-506.

62. Weng SH, Shing RK, Biing TG, Tsung YC, Hsin WH, Chieh WS (2007). Microclimatic responses to different thinning intensities in a Japanese cedar plantation of northern Taiwan. Forest Ecology and Management. 241: 91-100.

63. Whitmore TC (1998). An introduction to tropical rain forests. Oxford University Press, New York (USA).

64. Yemefack M, Rossiter DG, Jetten VG (2006). Empirical modeling of soil dynamics along chronosequence of shifting cultivation in southern Cameroon. Geoderma 133: 380-397.

65. Zar JH (1984). Biostatistical Analysis. Prentice-Hall, London.

66. Zhu JJ, Tan H, Li FQ, Chen M, Zhang JX (2007). Microclimate regimes following gap formation in a montane secondary forest of eastern Liaoning Province, China. Journal of Forest Research 18: 163-173.

How to Cite this Article: Chanhsamone Phongoudome, Don Koo Lee, Silavanh Sawathvong, Marilyn S. Combalicer, et al,. "Natural Regeneration and Tree Species Composition of Mixed Deciduous Forest after Logging and Shifting Cultivation in Lao PDR," Science Journal of Agricultural Research \& Management,Volume 2012, Article ID sjarm-298, 10 Pages, 2012. doi: 10.7237/sjarm/298 
Figure 1. The location of the study site in Bolikhan District, Bolikhamxay Province, Laos

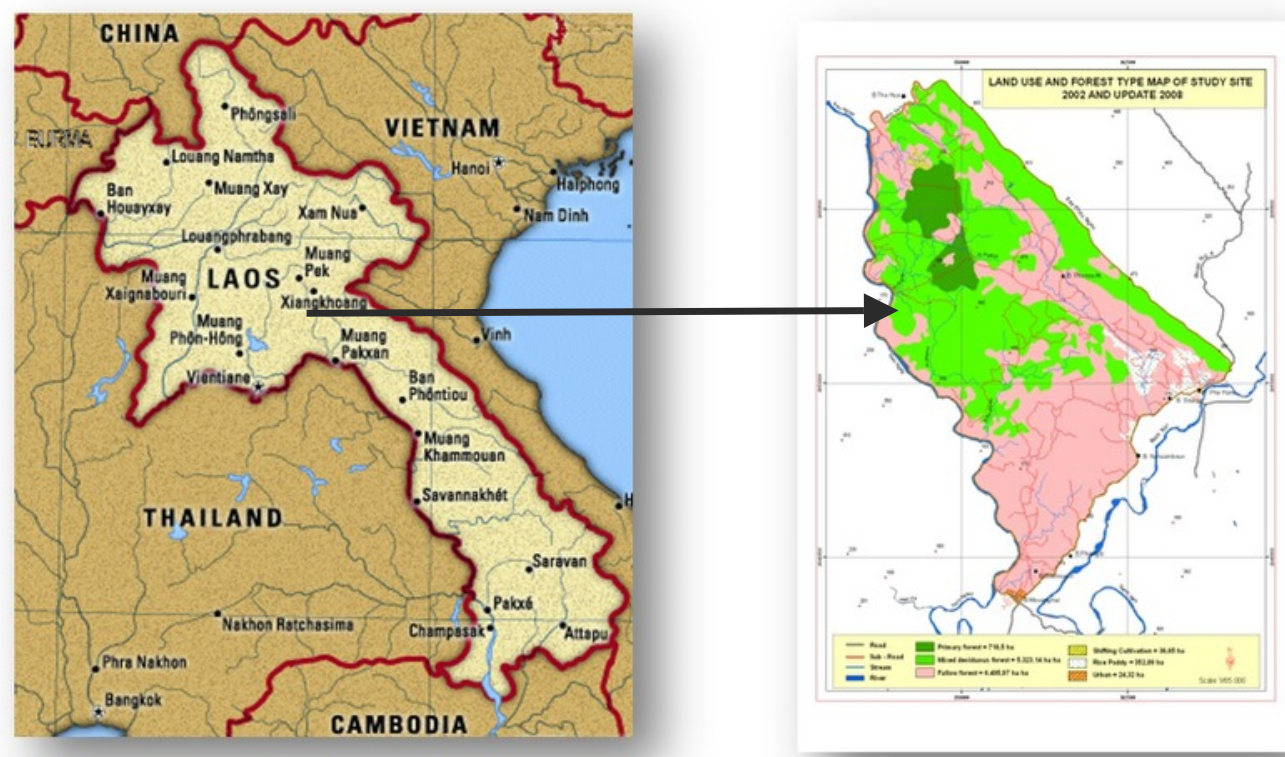

Figure 2. Distribution patterns of DBH and height in study area (A-B)

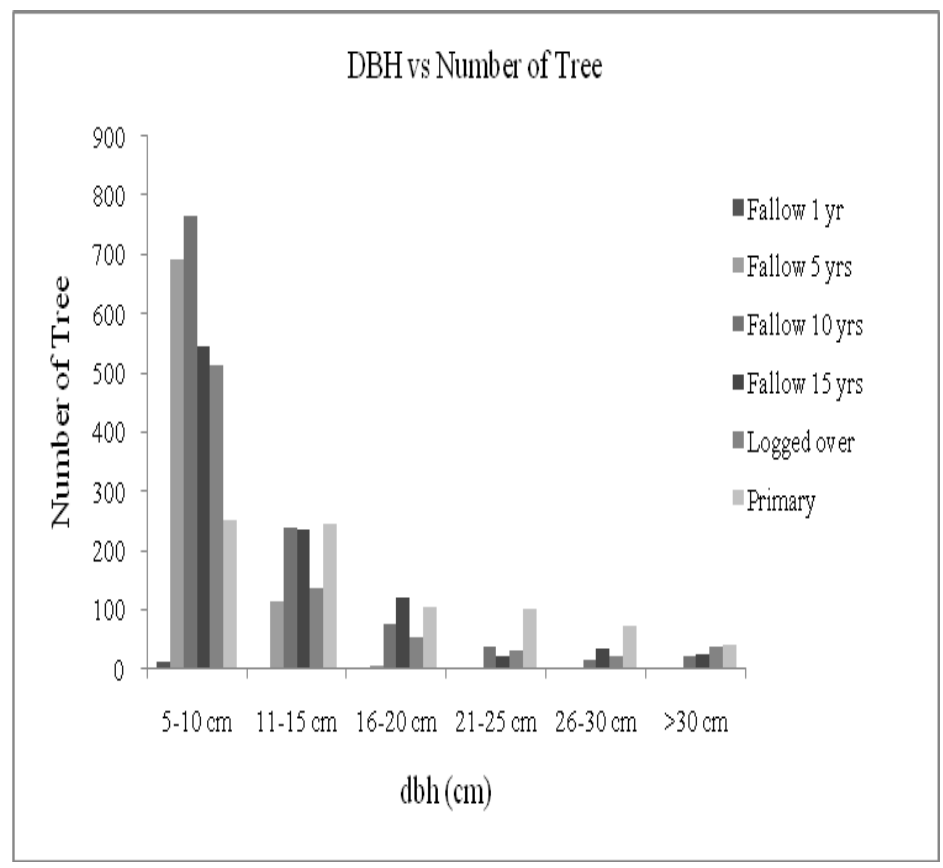

(A)

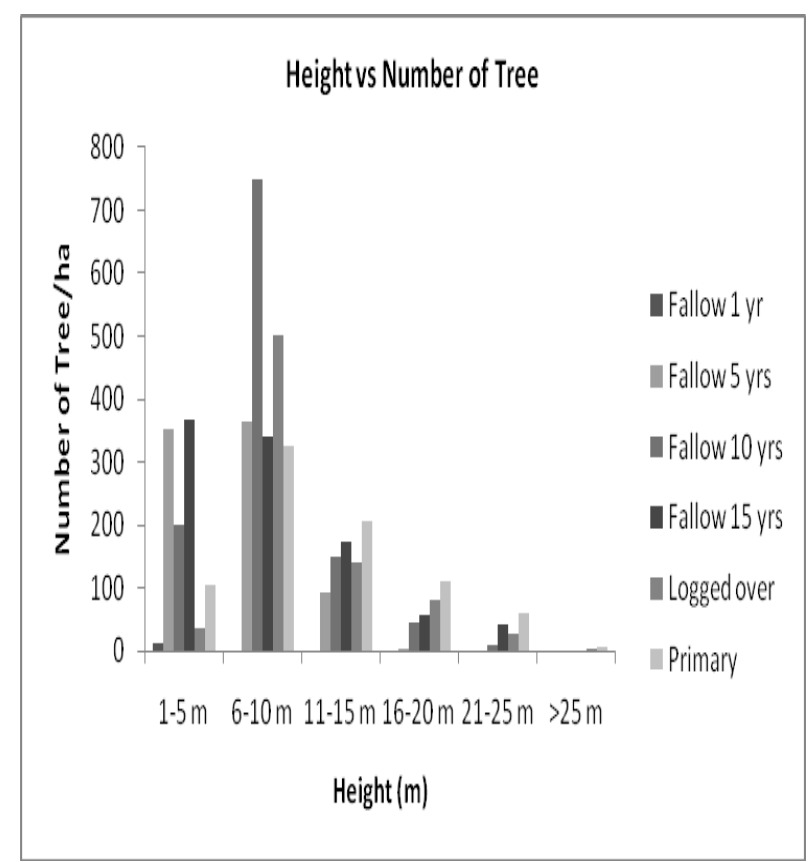

(B)

How to Cite this Article: Chanhsamone Phongoudome, Don Koo Lee, Silavanh Sawathvong, Marilyn S. Combalicer, et al,. "Natural Regeneration and Tree Species Composition of Mixed Deciduous Forest after Logging and Shifting Cultivation in Lao PDR," Science Journal of Agricultural Research \& Management,Volume 2012, Article ID sjarm-298, 10 Pages, 2012. doi: 10.7237/sjarm/298 
Table 1. Equation used for stand structure and species composition analysis

\begin{tabular}{|c|c|c|}
\hline Series no. & Equations & Remarks \\
\hline 1 & IVI $(\%)=(R A+R F+R D) / 3$ & $\begin{array}{l}\text { Where RA is the relative abundance, } \\
\mathrm{RF} \text { is the relative frequency, RD is the } \\
\text { relative dominance (Curtis and } \\
\text { McIntosh, 1950) }\end{array}$ \\
\hline 2 & $H^{\prime}=-\sum_{i=1}^{s} p i 1 n p i$ & $\begin{array}{l}\text { Where Shannon diversity index (H'), } \\
\text { pi is the proportion of the individuals } \\
\text { in the ith species, the values of } \mathrm{H}^{\prime} \\
\text { were compared through t-test } \\
\text { according to Magurran (1987). } \\
\text { (Pielou, 1975; Shannon and Weaver, } \\
\text { 1949; Magurran, 1987; Zar, 1984) }\end{array}$ \\
\hline 3 & $H j=\frac{j}{r}$ & $\begin{array}{l}\text { Jaccard' similarity index was } \\
\text { calculated as follow, Where } j \text { is } \\
\text { number of the same species found in } \\
\text { both communities and r total species } \\
\text { found in both communities. }\end{array}$ \\
\hline 4 & $D=\sum_{i=1}^{S}\left[\frac{n_{i}\left(n_{i}-1\right)}{N(N-1)}\right]$ & $\begin{array}{l}\text { Where Simpson's diversity index } \\
\text { where, } \mathrm{D} \text { is the Simpson's index of } \\
\text { diversity, ni is the number of } \\
\text { individuals of species "i" in the } \\
\text { sample, s is the number of species in } \\
\text { the sample, and N is the total number } \\
\text { of individuals in the sample }\end{array}$ \\
\hline 5 & $E(\%)=100\left(\frac{H^{\prime}}{I n H_{\max }}\right)$ & $\begin{array}{l}\text { Shannon evenness index, Evenness } \\
\text { index, a structural composition index, } \\
\text { which reflects the dominance of } \\
\text { species, where, E is the Shannon's } \\
\text { evenness (evenness measure, range } \\
0-1 \text { ), H' is the Shannon diversity } \\
\text { index, Hmax is the ln (S), and S is the } \\
\text { number of total species found in the } \\
\text { sample plot. }\end{array}$ \\
\hline
\end{tabular}


Table 2. Vegetation characteristics of primary and secondary forests (logged-over and fallow)

\begin{tabular}{|c|c|c|c|c|c|c|}
\hline $\begin{array}{c}\text { Vegetation } \\
\text { characteristics }\end{array}$ & Primary forest & $\begin{array}{c}\text { Logged-over } \\
\text { forest }\end{array}$ & $\begin{array}{c}\text { 15-year-old } \\
\text { fallow }\end{array}$ & $\begin{array}{c}\text { 10-year-old } \\
\text { fallow }\end{array}$ & $\begin{array}{c}\text { 5-year-old } \\
\text { fallow }\end{array}$ & $\begin{array}{c}\text { 1-year-old } \\
\text { fallow }\end{array}$ \\
\hline $\begin{array}{c}\text { Stem density } \\
\text { (n/ha) }\end{array}$ & $810(61)$ & $793(74)$ & $980(92)$ & $1,153(69)$ & $813(73)$ & $12(3)$ \\
\hline $\begin{array}{c}\text { Sampling } \\
\text { density (n/ha) }\end{array}$ & $2,476(1,240)$ & $6,386(1,627)$ & $10,536(3,652)$ & $5,993(1,132)$ & $6,250(1,002)$ & $1,000(408)$ \\
\hline $\begin{array}{c}\text { Seedling } \\
\text { density (n/ha) }\end{array}$ & $4,050(1,389)$ & $1,932(422)$ & $8,393(3,135)$ & $2,500(1,051)$ & $1,964(1,002)$ & $408(250)$ \\
\hline Species number & $77(0.62)$ & $82(0.49)$ & $45(0.86)$ & $44(0.80)$ & $31(0.40)$ & $25(0.89)$ \\
\hline Family number & $35(0.46)$ & $30(0.39)$ & $25(0.69)$ & $24(0.56)$ & $21(0.30)$ & $15(0.66)$ \\
\hline $\begin{array}{c}\text { Basal area } \\
\text { (m2/ha) }\end{array}$ & $50.30(4.13)$ & $38.92(6.94)$ & $30.51(2.93)$ & $24.43(0.08)$ & $11.42(0.03)$ & $1.05(0.09)$ \\
\hline $\begin{array}{c}\text { Volume density } \\
\text { (m3/ha) }\end{array}$ & $316.87(40.85)$ & $275.73(67.54)$ & $150.95(19.72)$ & $120.24(0.45)$ & $47.75(0.20)$ & $1.34(0.17)$ \\
\hline $\begin{array}{c}\text { Canopy cover } \\
\text { (m2/ha) }\end{array}$ & $4,773(596)$ & $3,027(208)$ & $4,489(320)$ & $2,130(173)$ & $3,087(780)$ & $43.3(5)$ \\
\hline $\begin{array}{c}\text { Litter layer and } \\
\text { litter-fall (t/ha) }\end{array}$ & $4.8(0.44)$ & $7.1(0.45)$ & $4.1(0.44)$ & $5.3(0.53)$ & $3.7(0.33)$ & $3.4(0.59)$ \\
\hline \begin{tabular}{c} 
DBH (cm) \\
\hline Height (m)
\end{tabular} & $15.69(0.6)$ & $12.58(1.01)$ & $12.19(0.63)$ & $10.93(0.45)$ & $7.49(0.30)$ & $2.27(0.11)$ \\
\hline
\end{tabular}

\begin{tabular}{|c|c|c|c|c|c|c|}
\hline Shannon's (H') & $3.40^{\mathrm{a}}$ & $3.09^{\mathrm{b}}$ & $2.91^{\mathrm{b}}$ & $2.72^{\mathrm{c}}$ & $2.71^{\mathrm{c}}$ & $2.13^{\mathrm{d}}$ \\
\hline Simpson's (D) & $0.98^{\mathrm{a}}$ & $0.91^{\mathrm{ab}}$ & $0.78^{\mathrm{bc}}$ & $0.62^{\mathrm{c}}$ & $0.86^{\mathrm{b}}$ & $0.78^{\mathrm{bc}}$ \\
\hline $\begin{array}{c}\text { Species } \\
\text { evenness (J') }\end{array}$ & $0.62^{\mathrm{ab}}$ & $0.66^{\mathrm{a}}$ & $0.36^{\mathrm{b}}$ & $0.35^{\mathrm{b}}$ & $0.25^{\mathrm{c}}$ & $0.20^{\mathrm{cd}}$ \\
\hline $\begin{array}{c}\text { Family } \\
\text { evenness (J') }\end{array}$ & $0.85^{\mathrm{a}}$ & $0.73^{\mathrm{ab}}$ & $0.61^{\mathrm{b}}$ & $0.59^{\mathrm{bc}}$ & $0.51^{\mathrm{c}}$ & $0.37^{\mathrm{d}}$ \\
\hline
\end{tabular}

Value in parenthesis indicates standard error and different letters indicate significant differences using DMRT 
Table 3. Changes in the importance value (\%) of different tree species in the primary and secondary (logged-over

\begin{tabular}{|c|c|c|c|c|c|c|c|}
\hline No. & Species & $\begin{array}{c}\text { Primary } \\
\text { forest }\end{array}$ & $\begin{array}{c}\text { Logged over } \\
\text { forest }\end{array}$ & $\begin{array}{c}\text { 15-year-old } \\
\text { fallow }\end{array}$ & $\begin{array}{c}\text { 10-year-old } \\
\text { fallow }\end{array}$ & $\begin{array}{c}5 \text {-year-old } \\
\text { fallow }\end{array}$ & $\begin{array}{c}\text { 1-year-old } \\
\text { fallow }\end{array}$ \\
\hline 1 & $\begin{array}{c}\text { Schima } \\
\text { wallichii }\end{array}$ & $\underline{17.22}$ & $\underline{6.4}$ & 2.34 & $\underline{5.14}$ & $\underline{6.67}$ & $\underline{3.42}$ \\
\hline 2 & $\begin{array}{c}\text { Castanopsis } \\
\text { sp } \\
\end{array}$ & $\underline{8.06}$ & $\underline{2.91}$ & $\underline{4.67}$ & - & - & - \\
\hline 3 & $\begin{array}{c}\text { Anisoptera } \\
\text { costata }\end{array}$ & $\underline{6.62}$ & 2.28 & 1.65 & 0.47 & - & - \\
\hline 4 & $\begin{array}{c}\text { Measua } \\
\text { ferrea } \\
\end{array}$ & $\underline{5.48}$ & $\underline{2.32}$ & 1.79 & 1.85 & - & - \\
\hline 5 & $\begin{array}{l}\text { Cratoxylum } \\
\text { formosum }\end{array}$ & $\underline{3.4}$ & - & - & - & - & - \\
\hline 6 & Eugenia ssp & $\underline{3.36}$ & 2.16 & $\underline{3.88}$ & $\underline{2.73}$ & 2.28 & 1.88 \\
\hline 7 & $\begin{array}{l}\text { Arytera } \\
\text { litoralis }\end{array}$ & $\underline{3.05}$ & 1.62 & 2.06 & 2.12 & 1.57 & - \\
\hline 8 & $\begin{array}{l}\text { Glochidion } \\
\text { fagifolium }\end{array}$ & $\underline{2.99}$ & 2.19 & $\underline{4.43}$ & $\underline{7.37}$ & $\underline{6.93}$ & 1.42 \\
\hline 9 & $\begin{array}{l}\text { Dipterocar } \\
\text { pus alatus }\end{array}$ & $\underline{2.67}$ & - & - & - & - & - \\
\hline 10 & $\begin{array}{c}\text { Sandoricum } \\
\text { indicum }\end{array}$ & $\underline{2.63}$ & 0.34 & 1.44 & 0.54 & - & - \\
\hline 11 & $\begin{array}{c}\text { Aporosa } \\
\text { microcalyx }\end{array}$ & 2.23 & $\underline{9.93}$ & $\underline{15.58}$ & $\underline{17.1}$ & $\underline{8.76}$ & $\underline{22.47}$ \\
\hline 12 & $\begin{array}{l}\text { Irvingia } \\
\text { malayana }\end{array}$ & 1.89 & 1.07 & $\underline{4.2}$ & $\underline{3.93}$ & 2.46 & 1.29 \\
\hline 13 & $\begin{array}{c}\text { Ziziphus } \\
\text { cambodiana }\end{array}$ & 1.49 & 2.1 & $\underline{3.38}$ & $\underline{4.54}$ & - & $2 \cdot 00$ \\
\hline 14 & $\begin{array}{c}\text { Ormosia } \\
\text { cambodiana }\end{array}$ & 1.41 & 0.39 & $\underline{4.79}$ & 1.1 & 1.29 & - \\
\hline 15 & Croton joufra & 1.18 & 0.63 & - & 1.7 & $\underline{6.43}$ & $\underline{5 \cdot 20}$ \\
\hline 16 & $\begin{array}{c}\text { Dillenia } \\
\text { indica }\end{array}$ & 0.7 & 1.48 & 3.11 & $\underline{2.72}$ & $\underline{4.13}$ & - \\
\hline 17 & $\begin{array}{c}\text { Croton } \\
\text { crassifolius }\end{array}$ & 0.66 & - & - & - & - & $\underline{3.35}$ \\
\hline 18 & $\begin{array}{c}\text { Sp } 4 \text { (Xou khi } \\
\text { khouay) }\end{array}$ & 0.6 & 0.75 & - & 0.98 & $\underline{4.15}$ & - \\
\hline 19 & $\begin{array}{c}\text { Gmerina } \\
\text { arborea }\end{array}$ & 0.53 & 0.29 & - & 1.85 & 1.90 & $\underline{2.59}$ \\
\hline 20 & $\begin{array}{c}\text { Vitex } \\
\text { pubescens }\end{array}$ & 0.4 & 1.07 & 1.13 & 0.78 & $\underline{3.07}$ & - \\
\hline 21 & $\begin{array}{c}\text { Croton } \\
\text { argyratus }\end{array}$ & 0.28 & $\underline{5.02}$ & 0.94 & 1.2 & 1.90 & - \\
\hline 22 & $\begin{array}{l}\text { Macaranga } \\
\text { denticulata }\end{array}$ & - & 0.32 & - & - & $\underline{5.48}$ & $\underline{19.47}$ \\
\hline 23 & $\begin{array}{c}\text { Machilus } \\
\text { cochinchinen } \\
\text { sis } \\
\end{array}$ & - & 0.62 & $\underline{3.34}$ & 1.56 & $\underline{3.07}$ & - \\
\hline 24 & $\begin{array}{l}\text { Diospyros } \\
\text { malabarica }\end{array}$ & - & $\underline{2.39}$ & 0.42 & 0.42 & 0.99 & - \\
\hline
\end{tabular}

How to Cite this Article: Chanhsamone Phongoudome, Don Koo Lee, Silavanh Sawathvong, Marilyn S. Combalicer, et al,. "Natural Regeneration and Tree Species Composition of Mixed Deciduous Forest after Logging and Shifting Cultivation in Lao PDR," Science Journal of Agricultural Research \& Management,Volume 2012, Article ID sjarm-298, 10 Pages, 2012. doi: 10.7237/sjarm/298 


\begin{tabular}{|c|c|c|c|c|c|c|c|}
\hline 25 & $\begin{array}{c}\text { Macaranga } \\
\text { triloba }\end{array}$ & - & $\underline{2.44}$ & - & - & 0.15 & 1.42 \\
\hline 26 & $\begin{array}{c}\text { Lagerstroemia } \\
\text { balansae }\end{array}$ & - & $\underline{2.73}$ & - & - & - & - \\
\hline 27 & $\begin{array}{c}\text { Peltophorum } \\
\text { dasyrachis }\end{array}$ & - & $\underline{8.75}$ & 2.46 & $\underline{4.81}$ & 1.09 & $\underline{4.72}$ \\
\hline 28 & $\begin{array}{c}\text { Cratoxylum } \\
\text { cochinchinen } \\
\text { sis }\end{array}$ & - & $\underline{16 \cdot 20}$ & $\underline{15.99}$ & $\underline{17.31}$ & $\underline{9.67}$ & $\underline{8.5}$ \\
\hline $29-123$ & $\begin{array}{c}\text { Other species } \\
\end{array}$ & 33.15 & 23.6 & 22.4 & 19.78 & 28.82 & 22.27 \\
\hline
\end{tabular}

(-) The blank indicated no species exits and under line are indicate top ten dominant species of each forest types

Table 4. Changes in soil chemical properties after logging and shifting cultivation at $(0-20 \mathrm{~cm})$

\begin{tabular}{|c|c|c|c|c|c|c|c|c|c|c|c|c|}
\hline $\begin{array}{c}\text { Forest } \\
\text { types }\end{array}$ & pH & pH & Total & Organic & $\mathrm{C} / \mathrm{N}$ & OM & P-av & K-av & $\mathrm{Ca}++$ & Mg++ & $\mathrm{Na}++$ & $\mathrm{K}++$ \\
\hline & $\mathrm{H} 2 \mathrm{O}$ & $\mathrm{Kcl}$ & $\mathrm{N} \%$ & $\begin{array}{c}\text { Carbon } \\
\%\end{array}$ & ratio & $\%$ & ppm & ppm & $\begin{array}{c}\mathrm{mg} / 100 \\
\mathrm{~g}\end{array}$ & $\begin{array}{c}\mathrm{mg} / 100 \\
\mathrm{~g}\end{array}$ & $\begin{array}{c}\mathrm{mg} / 100 \\
\mathrm{~g}\end{array}$ & $\begin{array}{c}\mathrm{mg} / 100 \\
\mathrm{~g}\end{array}$ \\
\hline \multirow[t]{2}{*}{ Primary } & 3.93 & 3.71 & 0.13 & $\begin{array}{c}1.49 \\
(0.09)\end{array}$ & 11.71 & $\begin{array}{c}2.56 \\
(0.15)\end{array}$ & 2.75 & 32.94 & $\begin{array}{c}0.22 \\
(0.03)\end{array}$ & $\begin{array}{c}0.46 \\
(0.02)\end{array}$ & $\begin{array}{c}0.04 \\
(0.00)\end{array}$ & $\begin{array}{c}0.08 \\
(0.01)\end{array}$ \\
\hline & $(0.03)$ & $(0.03)$ & $(0.01)$ & & $(0.13)$ & & $(0.23)$ & (3.05) & & & & \\
\hline \multirow[t]{2}{*}{$\begin{array}{l}\text { Logged- } \\
\text { over }\end{array}$} & 4.29 & 3.89 & 0.13 & $\begin{array}{c}1.44 \\
(0.15)\end{array}$ & 10.66 & $\begin{array}{c}2.48 \\
(0.26)\end{array}$ & 1.46 & 106.32 & $\begin{array}{c}0.32 \\
(0.08)\end{array}$ & $\begin{array}{c}0.52 \\
(0.05)\end{array}$ & $\begin{array}{c}0.18 \\
(0.02)\end{array}$ & $\begin{array}{c}0.25 \\
(0.15)\end{array}$ \\
\hline & $(0.06)$ & $(0.04)$ & $(0.01)$ & & $(0.32)$ & & $(0.12)$ & (19.41) & & & & \\
\hline \multirow[t]{2}{*}{$\begin{array}{l}\text { Fallow } \\
\text { (15yrs) }\end{array}$} & 4.24 & 3.92 & 0.11 & $\begin{array}{c}1.12 \\
(0.19)\end{array}$ & 10.04 & $\begin{array}{c}1.92 \\
(0.33)\end{array}$ & 1.38 & 56.97 & $\begin{array}{c}0.28 \\
(0.04)\end{array}$ & $\begin{array}{c}0.56 \\
(0.05)\end{array}$ & $\begin{array}{c}0.24 \\
(0.01)\end{array}$ & $\begin{array}{c}0.21 \\
(0.15)\end{array}$ \\
\hline & $(0.02)$ & $(0.04)$ & $(0.01)$ & & $(0.79)$ & & $(0.37)$ & $(9.46)$ & & & & \\
\hline \multirow[t]{2}{*}{$\begin{array}{l}\text { Fallow } \\
\text { (10yrs) }\end{array}$} & 3.93 & 3.75 & 0.17 & $\begin{array}{c}1.74 \\
(0.12)\end{array}$ & 10.52 & $\begin{array}{c}3.00 \\
(0.21)\end{array}$ & 2.25 & 61.87 & $\begin{array}{c}0.29 \\
(0.03)\end{array}$ & $\begin{array}{c}0.44 \\
(0.03)\end{array}$ & $\begin{array}{c}0.09 \\
(0.02)\end{array}$ & $\begin{array}{c}0.17 \\
(0.04)\end{array}$ \\
\hline & $(0.05)$ & (0.05) & $(0.01)$ & & $(0.38)$ & & (0.29) & (5.35) & & & & \\
\hline \multirow[t]{2}{*}{$\begin{array}{l}\text { Fallow } \\
\text { (5yrs) }\end{array}$} & 4.05 & 3.83 & 0.16 & $\begin{array}{c}1.66 \\
(0.11)\end{array}$ & 10.39 & $\begin{array}{c}2.87 \\
(0.18)\end{array}$ & 2.24 & 90.16 & $\begin{array}{c}0.29 \\
(0.02)\end{array}$ & $\begin{array}{c}0.45 \\
(0.01)\end{array}$ & $\begin{array}{c}0.09 \\
(0.03)\end{array}$ & $\begin{array}{c}0.20 \\
(0.03)\end{array}$ \\
\hline & $(0.05)$ & $(0.05)$ & $(0.01)$ & & $(0.32)$ & & $(0.14)$ & (7.77) & & & & \\
\hline \multirow[t]{2}{*}{$\begin{array}{l}\text { Fallow } \\
(1 \mathrm{yr})\end{array}$} & 4.1 & 3.87 & 0.15 & $\begin{array}{c}1.58 \\
(0.12)\end{array}$ & 10.67 & $\begin{array}{c}2.66 \\
(0.20)\end{array}$ & 2.59 & 81.27 & $\begin{array}{c}0.28 \\
(0.03)\end{array}$ & $\begin{array}{c}0.45 \\
(0.02)\end{array}$ & $\begin{array}{c}0.10 \\
(0.02)\end{array}$ & $\begin{array}{c}0.15 \\
(0.02)\end{array}$ \\
\hline & $(0.05)$ & $(0.04)$ & $(0.01)$ & & $(0.39)$ & & $(0.24)$ & (5.29) & & & & \\
\hline
\end{tabular}

Value in parenthesis indicated standard error 